\title{
História da Eletricidade e do Magnetismo: da Antiguidade à Idade Média
}

The History of Electricity and Magnetism: from antiquity to middle ages

\author{
Danny Augusto Vieira Tonidandel ${ }^{* 1,}$ 이, Antônio Emílio Angueth de Araújo² ${ }^{2}$, Wallace do Couto \\ Boaventura $^{2}$
${ }^{1}$ Universidade Federal de Ouro Preto, Departamento de Engenharia de Controle e Automação, Campus Morro do Cruzeiro, s/n, Ouro Preto, MG, Brasil
${ }^{2}$ Universidade Federal de Minas Gerais, Departamento de Engenharia Elétrica, Belo Horizonte, MG, Brasil
${ }^{3}$ Universidade Federal de Minas Gerais, Programa de Pós-graduação em Engenharia Elétrica, Belo Horizonte, MG, Brasil

Recebido em 16 de Fevereiro, 2018. Revisado em 28 de Maio, 2018. Aceito em 28 de Maio, 2018.

\begin{abstract}
Os conceitos de eletricidade e magnetismo, muito antes de figurarem como aspectos basilares da ciência e tecnologia contemporânea, tiveram suas virtudes cantadas em prosa e verso, analisadas em perquirições filosóficas, enaltecidas em tratados morais, aplicadas na medicina e até na literatura mitológica. A história de sua descoberta, que acreditamos ainda não ter sido concluída, se confunde com a própria história do conhecimento humano, desde épocas remotas. Considerando sua importância, buscar-se-á, portanto, tecer alguns fatos e narrativas a respeito da formação dos conceitos de eletricidade e magnetismo ao longo da história antiga até a Idade Média, visando contribuir com os estudos relativos a este recorte temporal no contexto da física.
\end{abstract}

Palavras-chave: História da Física, história da eletricidade e do magnetismo.

\begin{abstract}
The concepts of electricity and magnetism, way before appearing as fundamental aspects of contemporary science and techonology, had their virtues sung in prose and verse, analyzed in philosophical studies, extolled in moral treatises, applied in medicine and, even in mythological literature. The history of its discovery, which we believe has not yet been completed, is confused with the very history of human knowledge, since remote times. Considering its importance, we will therefore try to weave some facts and narratives regarding to the formation of the concepts of electricity and magnetism throughout ancient history until the Middle Ages, in order to contribute with the studies related to this temporal cut in the context of physics.
\end{abstract}

Keywords: History of physics, History of electricity and magnetism.

\section{Introdução}

Prosa e poesia, ética e moral, medicina e mitologia se entrelaçam nos primeiros relatos conhecidos sobre eletricidade e magnetismo. Muito antes de se tornarem objeto de ciência, observadores da Antiguidade notavam que determinados materiais, ora submetidos ao atrito com materiais de natureza diferente, cediam ou recebiam determinadas "virtudes", que pareciam transferir-se de um corpo ao outro, fazendo com que estes, ora inertes, ganhassem propriedades similares ao da "pedra ímã". A "capacidade de transferência" sugeria que um entre material, dotado de massa, jornadeava livremente entre os corpos - desde que estabelecido um caminho tornando-os concentrados ou "carregados". Tais virtudes foram enaltecidas em diversas produções, que acabaram por formar, ao longo do tempo, o inventivo e genioso caminho de descoberta dos fenômenos eletromagnéticos. Neste contexto, buscamos apresentar fatos e narrativas acerca da história da eletricidade e do magnetismo em

*Endereço de correspondência: tonidandel@ufop.edu.br um recorte temporal que vai da Antiguidade até a Idade Medieval, culminando em trabalhos que sedimentaram um dos pilares fundamentais da física e tecnologia contemporâneas, o conceito de campo.

\section{Do século XXVII a.C, na China, até os gregos antigos}

Parece haver indícios de que o homem usava propriedades magnéticas de certas substâncias num passado longínquo. Registros históricos indicam que no ano de 2637 a.C., as tropas do imperador chinês Huang-ti se perderam na enevoada planície de Tchu-lu, quando perseguiam as tropas inimigas do príncipe rebelde Tchi-yu. Dadas as circunstâncias, Huang-ti construiu uma carruagem sobre a qual uma grande figura feminina, de braços abertos, girava livremente de modo a sempre indicar o sul, qualquer que fosse a direção tomada pela carruagem. Suspeita-se, com muita razão, que ligada a essa figura houvesse uma espécie de agulha magnética que lembrasse uma bússola [1]. A este registro tão antigo seguem-se outros, todos na China. 
São aplicações da chamada tchi-nan, ou "carruagem do sul".

O primeiro registro não chinês de fenômenos elétricos ou magnéticos ocorre na Grécia, no século VI a.C. Sabemos, por terceiros, que Tales, uma mistura de filósofo e cientista prático, na expressão de Copleston [2], teria conhecido (ou descoberto) fenômenos elétricos associados ao âmbar, bem como fenômenos magnéticos associados a uma pedra encontrada na região de Magnésia. Aristóteles é o primeiro a citar Tales e os fenômenos magnéticos, no seu tratado sobre a alma:

"Parece que também Tales, a avaliar pelo que se conta, considerava a alma como algo de cinético, se é que ele disse que a pedra [de Magnésia] possui alma pelo fato de deslocar o ferro." 3

"Tales, também, a julgar dos registros sobre ele, parece ter acreditado que a alma era o fundamento da força, pois ele dizia que o ímã tem uma alma em seu interior porque move o ferro." [4]

Diógenes Laércio, historiador e biógrafo dos antigos filósofos gregos, que viveu no século II, diz em sua obra Vidas e Doutrinas dos Filósofos Ilustres que:

"Aristóteles e Hípias afirmam que ele [Tales] partilhou a alma até pelos objetos inanimados, servindo-se da pedra de Magnésia e do âmbar como indício desse conceito."

Deve-se ter certa cautela acerca do fato de Tales ter realmente tido contato com os fenômenos elétricos exibidos pelo âmbar quando atritado. Aristóteles, um sujeito meticuloso em suas afirmações, não menciona nada sobre o âmbar quando fala de Tales, mencionando apenas a pedra-ímã. Aqui há de se acrescentar que a pedra-ímã é um aspecto muito importante no desenvolvimento das concepções filosóficas de Tales, considerado como um dos fundadores da filosofia ocidental. É difícil crer que o âmbar, tendo o poder de atrair objetos, não tenha sido incluído por Tales como um dos exemplos de coisas naturais possuidoras de alma. Ou, por outro lado, que Tales tenha de fato mencionado o âmbar como algo animado e que Aristóteles tenha deixado de mencioná-lo. De qualquer forma, a referência mais antiga ao âmbar e sua relação com Tales, vem de Diógenes Laércio, cuja confiabilidade como historiador já foi posta em questão em muitas oportunidades. 5

Se o relato de Laércio for desprezado, o próximo relato mais antigo sobre o âmbar, este muito mais confiável, é o de Platão, no Timeu:

"O mesmo se passa com todos os fluxos de água, a queda de raios, as maravilhas da atração do âmbar e da pedra de Héracles ${ }^{1}$ A atração não intervém de qualquer modo em nenhum de todos

${ }^{1} \mathrm{~A}$ pedra-ímã. estes objetos, mas será evidente para quem os investigar adequadamente que é por causa destes acidentes (em virtude de não existir o vazio e de eles se empurrarem em círculos entre si, por vezes separando-se e por vezes combinando-se, trocando de lugar entre si e dirigindo-se todos para o que lhes é próprio) que eles se entretecem uns com os outros e fabricam fenômenos admiráveis." 6

Theophrastrus (371-287a.C.), sucessor de Aristóteles no Lyceum, menciona tanto a pedra-ímã quanto o âmbar em sua obra Sobre as Pedras [7]:

\footnotetext{
"Dentre as substâncias que são extraídas da terra, porque são úteis, as que são conhecidas como carvão são feitas de terra, e pegam fogo. Elas são encontradas em Ligúria, onde também é encontrado o âmbar, e em Élis, no caminho montanhoso até Olímpia."
}

Este filósofo parece ter sido também o primeiro a mencionar, nesse mesmo tratado, outra substância, além do âmbar, que exibia propriedades elétricas:

"Lyngourion é muito dura e parece com uma pedra. Ela tem o poder de atração, tal como o âmbar, e alguns dizem que ela não somente atrai palha e pequenos pedaços de madeira, mas também o cobre e o ferro, se estes forem bem finos."

A natureza precisa do lyngourion foi, ao longo dos séculos, um pomo de discórdia, e as especulações a esse respeito são volumosas. Parece ter havido certo consenso no século XVII sobre ser o lyngourion a turmalina, mas mesmo isso é discutível. Alguns afirmaram até que Theophrastus teria confundido o próprio âmbar e lhe dado um outro nome.

\section{Titus Lucretius Carus, no século I a.C}

Lucretius foi um poeta e filósofo romano, seguidor de Epicuro, que viveu entre 99 e 55 a.C. Ele escreveu um poema que procurava fundamentar a filosofia epicurista (um materialismo radical) em observações sobre os fenômenos naturais. No livro VI desse longo poema (De Rerum Natura, Da Natureza das Coisas), ele se mostra não só filósofo, mas também uma espécie de físico experimental pioneiro. Ele afirma, logo de início [8]:

"Vou agora começar a explicar outro assunto, a dizer por que leis naturais pode atrair ao ferro a pedra a que chamam os gregos magnete, nome que lhe designa a origem, porquanto se diz que provém de Magnésia. Os homens admiram esta pedra; com efeito, muitas vezes se vê formar uma cadeia com vários anéis que dela pendem. É possível verem-se cinco e mais ainda, suspensos uns dos outros, balançar-se nas ligeiras auras, uns aos outros passando a força e as ligações 
da pedra, de modo que essa força se exerça sem interrupções.

Em tudo o que é desta espécie se têm de pôr muitos fundamentos antes que se possa apresentar a própria razão do fenômeno e é com grandes voltas que se tem de fazer a aproximação; por isso, peço agora ânimo e ouvidos mais atentos."

Lucretius começa então uma longa digressão, onde vai tentar construir uma explicação dos fenômenos magnéticos por ele descritos. Começa falando da emanação de várias coisas dos corpos materiais:

\begin{abstract}
"Primeiro, deve haver de todos os corpos que nós vemos um perpétuo fluxo, uma emissão, um emanar de elementos que nos impressionam os olhos e os movem à visão. Perpetuamente fluem os cheiros de certos corpos, como o frio sai dos rios, o calor do Sol, e das ondas do mar, a vaga que vai roendo os diques do litoral."
\end{abstract}

E continua observando acerca das coisas que têm estrutura rarefeita:

\begin{abstract}
"Vemos, primeiro, que, nas cavernas, as pedras de cima como que suam um líquido e gota a gota o vão destilando e fazendo correr. Assim também a nós mana o suor por todo o corpo e nos cresce a barba, nos crescem os pêlos por todo o corpo."
\end{abstract}

Nesta longa descrição, há que se destacar alguns trechos em que Lucretius concentra sua explicação. Depois de dizer que algo sai da pedra-ímã e dissipa o ar a sua frente, ele diz:

"Logo que o espaço se encontra vazio, logo que se despeja o lugar que está no meio, imediatamente os elementos do ferro, caindo, se lançam juntos no vácuo, de maneira que o próprio anel os segue e vai com toda a sua substância."

Mais à frente, ele aduz outro fenômeno auxiliar:

"Vem ainda sobre isto que uma outra causa torna mais fácil o fenômeno, e, chegando como ajuda, lhes auxilia o movimento: efetivamente, logo que o ar que está à frente do anel se rarefaz e o lugar se torna mais livre e vazio, logo sucede que todo o ar que se encontra por detrás como que empurra e impele para a frente."

Note ainda que Lucretius explica aqui não só a atração, como a repulsão magnética:

\footnotetext{
"Acontece também que algumas vezes foge desta pedra a substância do ferro, habituada como está a alternadamente se retirar e seguir."
}

Esta parece ser a primeira vez que o homem tenta uma explicação, para além de uma simples descrição, de um fenômeno magnético. Ademais, é interessante notar que Lucretius coleta dados experimentais para fundamentar sua análise: "Eu mesmo vi saltarem pedaços de ferro da Samotrácia ...".
Talvez não seja exagero ver na descrição de Lucretius alguma antecipação da teoria dos vórtices que seria formulada mais de 1500 anos depois por Descartes. A menção à limalha de ferro é também notável e deixa a dúvida se Lucretius teria se deparado com as figuras magnéticas segundo as quais a limalha se distribui quando próxima a ímãs. Tais figuras tiveram grande impacto na concepção do campo eletromagnético desenvolvido por Michael Faraday, como é notório. É importante observar que a ideia de emanação, de algo que sai dos corpos e preenche o ar em torno, agindo nos corpos próximos, será retomada por muitos filósofos naturais ao longo dos séculos.

Não se pode deixar de notar ainda que Lucretius usa a analogia entre algo aparentemente explicado: "Vemos, primeiro, que, nas cavernas, as pedras de cima como que suam um líquido e gota a gota o vão destilando e fazendo correr. Assim também a nós mana o suor por todo o corpo," para tentar explicar algo então ainda inexplicado. Milênios depois, Maxwell, em seu primeiro artigo sobre o eletromagnetismo 9], afirma que:

(...) "Devemos, portanto, descobrir algum método de investigação que nos permita, a cada passo, desenvolver uma clara concepção física, sem nos comprometer com qualquer teoria fundada na ciência física da qual tal concepção foi retirada, de modo que não nos percamos na busca de sutilezas analíticas, nem ultrapassemos a linha da verdade levados por uma hipótese de especial predileção.

Para se obter ideias físicas sem adotar uma teoria física, devemos nos familiarizar com a existência de analogias físicas. Analogia física, a meu ver, é aquela parcial similaridade entre as leis de uma ciência e aquelas de outra que faz cada qual ilustrar a outra."

Plutarco, quase duzentos anos depois de Lucretius, repete a teoria do poeta romano (Questão VII, Questões Platônicas):

"Nem o âmbar nem a pedra-ímã atrai nada que está perto, nem tampouco algo espontaneamente deles aproxima. Mas essa pedra emite exalações extensas, por meio das quais o ar em torno é impelido e, por sua vez, força o que está diante dele; e isto acontecendo em círculos, retornando ao local evacuado, ele atrai forçosamente o ferro na mesma direção. No âmbar há uma natureza flamejante e espirituosa que é emitida desde passagens reclusas pela fricção da superfície, e ele faz o mesmo que a pedra-ímã. O âmbar também atrai os corpos mais leves e secos, porque delicados e fracos; pois ele não é tão forte nem imbuído de peso e força para coagir muito ar a agir com violência e ter o poder sobre corpos grandes, como o magnete tem. Mas, qual a razão de o ar nunca mover uma pedra, nem um pedaço de madeira, mas tão somente o ferro, na direção da pedra-ímã? Esta é uma pergunta normal tanto para aqueles que pensam que a cópula desses corpos é feita por atração da pedra-ímã, quanto para aqueles que pensam que ela é feita 
pelo incitamento do ferro. O ferro não é nem tão raro quanto a madeira, nem tão completamente sólido quanto o ouro ou uma pedra; mas tem certos poros e asperezas, que são proporcionais ao ar; e o ar sendo recebido em certos orifícios, e tendo (como parece) certa sustentação a que se agarrar, não escapa; mas quando é levado até à pedra e se choca com ela, ele leva o ferro à força até à pedra. Tal deve ser então a razão disso."

Com Lucretius a ciência do magnetismo teve seu tímido começo; ele estabeleceu o fenômeno da atração e repulsão magnética, com o auxílio inclusive de experimentos rudimentares, e desenvolveu um modelo não matemático da ação das forças magnéticas. Pelo que escreve, ele não parece ter observado o fato de que a pedra que atrai o ferro tinha duas regiões de propriedades opostas que hoje são conhecidas como polos.

\section{Referências literárias ao magnetismo e à bússola}

Por mais de 1200 anos, nada mais foi acrescido a esse conhecimento da antiguidade. Em tal período, alguns pensadores mostraram, por meio de seus escritos, que tomaram conhecimento do fenômeno magnético. O poeta latino Cláudio (Claudius Claudianus), no século IV, escreve um poema de 57 estrofes dedicado à pedra ímã, contendo apenas generalidade poética 10 .

Santo Agostinho também se refere ao magnetismo. Ele, em sua obra De Civitate Dei (A Cidade de Deus) diz o seguinte 11:

\begin{abstract}
"Sabemos ser estupenda a atração que o ímã exerce sobre o ferro. A primeira vez que o vi fiquei realmente estupefato. Víamos, com efeito, um anel de ferro levantado pela pedra-ímã; depois, como se comunicasse sua força ao ferro, o anel pegou outro, o levantou e esse se uniu a um terceiro, como o primeiro à pedra. Aproximaram um terceiro e um quarto e já ficava como uma corrente de anéis pendentes ligados uns aos outros, sem estarem interiormente enlaçados. Quem não pasmará da virtude dessa pedra, virtude que não estava só nela, mas passava de anel em anel e unia uns aos outros com laços invisíveis? Mas é muito mais surpreendente o que me contou Severo de Mileve, meu irmão e companheiro no episcopado. Comendo certo dia em casa de Batanário, conde de África outrora, viu, dizia ele, que, posta uma pedra-ímã debaixo de um prato de prata e em cima um pedaço de ferro, comunicou ao ferro todos os movimentos que a mão imprimia ao ímã e o fazia ir e vir a seu talante, sem que o prato de prata recebesse impressão alguma."
\end{abstract}

A bússola, primeiro artefato tecnológico que a ciência do magnetismo produziu, foi introduzida no Ocidente provavelmente pelas Cruzadas. Os cruzados, em sua volta à Europa, trouxeram o artefato que tomaram ou compraram dos inimigos árabes. Estes tiveram contato com a bússola por meio dos chineses.

A bússola teve um impacto no imaginário do povo, como todo artefato tecnológico de grande influência tem, embora tenha sido criação que remodelou os próprios comportamentos e tendências das sociedades seguintes 12 .

No longínquo ano de 1208 , o poeta Guyot de Provins, trovador francês, talvez o primeiro a se referir à bússola, escreve um longo poema satírico, onde há a seguinte passagem:

"Os marinheiros empregam

Uma arte que não engana.

Uma pedra feia e marrom,

À qual se junta o ferro com gana.

Depois de lhe aplicarem uma agulha,

Eles a colocam numa vareta

E na água a lançam simplesmente

Onde pode flutuar seguramente.

Sua ponta se volta então diretamente

Para a estrela de modo tal

Que homem algum duvidará jamais, certamente.

Tampouco ela jamais errará, obviamente.

Quando o mar está escuro e brumoso,

Que ninguém vê nem estrela nem lua,

Eles iluminam a agulha

E não temem perder a trilha.

A ponta para a estrela se torna,

Ensinando os marinheiros

A seguir a correta trajetória.

É uma arte que não engana."

O poeta continua seu poema criticando cáustica e destemidamente, tanto leigos quanto clérigos, tanto nobres quanto príncipes, e até mesmo o pontífice reinante. Todos deveriam ser para seus súditos, segundo o satirista, como a estrela polar para os marinheiros - um farol a guiá-los no mar bravio da vida.

Numa clave muito mais séria, um código de leis espanhol conhecido como Las Siete Partidas del Rey Don Alfonso el Sabio, consigna o seguinte ${ }^{2}$

"Tal como os marinheiros se guiam nas noites escuras pela agulha, que é a medianeira entre a pedra-ímã e a estrela, e lhes mostra por onde vão, seja no mau tempo, seja no bom; assim aqueles que aconselham o rei, devem sempre se guiar, em todo o tempo, pela justiça, que é a medianeira entre Deus e o mundo, de modo a recompensar os bons e punir os maus, a cada um segundo seu merecimento 3

Aqui, a bússola serve como metáfora da mediação entre Deus e os homens. Não admira que seja um documento espanhol, pois os espanhóis e os portugueses foram os grandes beneficiários dessa tecnologia, que lhes permitiram conseguir a supremacia dos mares por meio dos grandes descobertas e feitos marítimos.

\footnotetext{
${ }^{2}$ As Sete Partidas, ou simplesmente Partidas, é um corpo normativo redigido em Castilla, durante o reinado de Alfonso X (1252-1284), com o objetivo de conseguir uma certa uniformidade jurídica do reino. Seu nome original era Livro das Leis, e no século XIV recebeu sua denominação atual, por causa das seções em que se dividia.

${ }^{3} \mathrm{E}$ bien assi como los marineros se guian en la noche escura por el aguja, que les es medianera entre la piedra e la estrella, e les muestra por de vayan, tambiem en los malos tiempos, como en los buenos; otrosi los que han de consejar al Rey, se deven siempre guiar por la justicia, que es medianera entre Dios e el mundo, en todo o tiempo, para dar gualardon a los buenos, e pena a los malos, a cada uno segund su merecimiento." (Partida 2, Título 9, Lei 28.)
} 
Já no século XIII, Brunetto Latini (1230-1294), preceptor de Dante em Florença e convidado do frade Roger Bacon em Oxford, escrevia em 1260:

"Os marinheiros navegam os mares guiados por duas estrelas chamadas tramontanas; e cada uma das duas partes da pedra dirige a agulha que tocou em direção a uma estrela particular, para a qual se volta aquela parte da pedra."

Há um erro na afirmação do eminente filósofo, estadista e orador, pois a parte da pedra que toca a agulha se volta para na direção oposta à da agulha, pois induz um magnetismo oposto na agulha.

O próprio Dante (1265-1321) parece admitir uma influência oculta que emana da estrela polar e influencia a agulha, quando escreve: 13

"De uma das luzes da coroa nova moveu-se a voz que à agulha, volta à estrela, me assemelhou, ao volver-se a outra nova." 4

Raimundo Lúlio (1236-1315) menciona em seu livro De Contemplatione, que:

"Na medida em que a agulha, depois de tocar a pedra-ímã, se volta para o norte, a agulha dos marinheiros os dirige ao longo dos mares."

\section{Referências mitológicas e medicinais ao magnetismo e à eletricidade}

Muitas fábulas foram acrescidas ao imaginário da humanidade acerca de fatos inverídicos sobre as propriedades de materiais magnéticos, desde a antiguidade até os dias atuais. O poeta Plínio, já no século I, parece ter sido o pioneiro dos criadores dos mitos magnéticos. Ele afirma que certo arquiteto planejava colocar uma grande pedra magnética, magnetita, na abóboda de um templo em Alexandria, com o propósito de manter uma estátua de ferro da Rainha Arsinoe suspensa no ar. Outra lenda é a sempre repetida história sobre o sarcófago de Maomé, que seria de ferro e que estaria levitando, pelo efeito de uma pedra de magnetita, entre o solo e o teto de um templo em Meca. Aqui, além do mito magnético, há também um erro histórico, pois Maomé foi enterrado em Medina. Ainda no século IV, Santo Ambrósio escreve sobre supostos mitos que lhe chegaram aos ouvidos; de que havia certas montanhas magnéticas na Índia que arrancavam os pregos de ferro dos navios que passavam à sua frente.

A literatura mitológica acerca do magnetismo se tornou abundante com o passar do tempo. Há o caso do ímã "carnal" que teria a extraordinária propriedade de se aderir à pele e até mesmo de arrancar, por atração magnética, o coração de um homem. Há o ímã-ouro que extrairia partículas do metal precioso quando misturadas à areia. Há os unguentos magnéticos, que quando aplicados na careca de um homem, faria o cabelo crescer; há os emplastros magnéticos para o alívio da dor de cabeça; há as aplicações para aliviar dor de dentes e curar depressão. Há as poções magnéticas para curar a hidropsia, para apaziguar briga de casais. Outra interessantíssima superstição fazia com que os marinheiros, responsáveis pela bússola, fossem proibidos de ingerir cebola

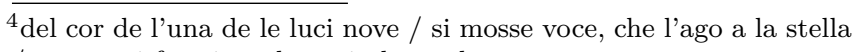
/ parer mi fece in volgermi al suo dove. ou alho, pois seu hálito perturbaria o "índice do polo", o que faria a bússola apontar para a direção errada. 14

Não se pode desconhecer que até hoje persistem mitologias sobre o campo magnético e sua influência. Há empresas especializadas em produtos magnéticos terapêuticos. Uma dessas empresas afirma em seu sit£ $\S^{5}$ que

"A regulação celular, as funções dos tecidos e a própria vida são controladas por correntes eletromagnéticas internas. Nos estados doentios, esses potenciais eletromagnéticos são alterados mas, felizmente, podem ser favoravelmente influenciados pela a aplicação de magnetismo externo."

Expressões cientificamente imprecisas - correntes eletromagnéticas internas, potenciais eletromagnéticos - denotam o amadorismo do texto e a tentativa de aproveitar a credulidade popular em pleno século XXI.

Há também referências aos efeitos medicinais associados ao âmbar. Em uma nota explicativa, na tradução para o inglês do livro de William Gilbert, De Magnete, Magneticisque Corporibus, et de Magno Magnete Tellure [Sobre os Ímãs, os Corpos Magnéticos e o Grande Ímã Terrestre] 15, Silvanus P. Thompson menciona, na nota 111, um trecho do livro de Plínio, o Velho, intitulado História Natural, em que o naturalista romano menciona que:

"Callistratus diz que o âmbar amarelo, usado num colar no pescoço, cura febre e doenças da boca, garganta e maxilar. Reduzido a pó e misturado ao mel e óleo de rosas, ele tem efeitos inigualáveis nas enfermidades do ouvido. Misturado ao mel, tem efeitos singulares como colírio. Em pó e ingerido com água é inigualável para males de estômago."

\section{Referências adicionais à eletricidade no início da Idade Média}

Duas passagens merecem aqui um registro. Uma brevíssima observação de Santo Agostinho, no século V, 16]

"a pedra-imã, que, com uma espécie de insensível sorvo, não move a palha e atrai o ferro."

Aqui Santo Agostinho observa, pela primeira vez, a diferença entre eletricidade (que move a palha) e o magnetismo (que atrai o ferro, mas não move a palha). Por que essa pedra tem o poder de atrair o pesado ferro, mas não consegue mover a palha? Tal pergunta teria de esperar muitos séculos para ser respondida.

No século VII, uma curta passagem na obra mais famosa do Venerável Beda (672-735), Historia Ecclesiastica Gentis Anglorum (História Eclesiástica do Povo Inglês), tem-se o seguinte (Liv. I, Cap. I):

"A Inglaterra tem fontes de águas minerais e fontes de águas quentes. (...) É rica em veios de metais, cobre, ferro, chumbo e prata; e também produz azeviche ${ }^{6}$ em grande quantidade e

\footnotetext{
${ }^{5}$ https://www.promagnet.com/informationpage.htm, acessado em 20/02/2014

${ }^{6}$ Carvão compacto usado como gema, também conhecido por âmbar negro (black amber). O azeviche teve um uso muito difundido no império romano, que transportava o produto da Inglaterra para Roma.
} 
qualidade. Essa pedra é negra e brilhante, e arde quando colocada no fogo: quando queimada, ela espanta serpentes; quando aquecida por fricção, ela atrai, como o âmbar, pequenas coisas que dela se aproximam.' 7

O Venerável Beda adiciona assim ao conhecimento humano, dez séculos depois de Theophrastus, mais uma substância similar ao âmbar e ao lyngourion, tendo o poder de atrair, depois de friccionada, pequenas coisas.

\section{Petrus Peregrinus, o grande experimentalista medieval}

Pode-se afirmar que, até o século XIII da era cristã, não houveram grandes avanços no conhecimento do magnetismo. É admirável observar quantos homens tiveram contato mais íntimo com os fenômenos magnéticos, tendo feito sua descrição, enaltecido suas virtudes em prosa e verso, e utilizando, inclusive, seus "recursos" como objetos mágicos. A bússola ocuparia, por séculos, o imaginário de muitos, tendo servido de metáfora inclusive para tratados morais.

Na segunda metade do século XIII, surge um homem que avançaria grandemente o conhecimento do magnetismo, e seu trabalho se constituiria um marco, sobretudo na física experimental. Petrus Peregrinus nasceu na vila de Maricourt, na Picardia, região ao norte da França. Do título de magister é possível inferir que ele tenha recebido a melhor instrução possível, talvez na Universidade de Paris, que era então muito afamada. A reputação de Peregrinus, acerca de seus conhecimentos matemáticos e habilidade experimental, alcançou, do outro lado do Canal, o frade Roger Bacon(1214-1294), na Universidade de Oxford. O frade Bacon não escondia a admiração que nutria por seu amigo da Picardia e em sua obra Opus Tertius dizia dele:

\begin{abstract}
"Conheço apenas uma pessoa que merece louvor por seu trabalho em filosofia experimental, porque ele não se atém ao discurso dos homens e aos seus arsenais de palavras, mas serena e diligentemente persegue as obras de sabedoria. Assim, o que os outros tateiam cegamente, como morcegos no crepúsculo, este homem contempla em todo o seu brilho, porque é um mestre do experimento."
\end{abstract}

E diz mais adiante:

"Ele conhece todas as ciências naturais, sejam as da medicina e alquimia, sejam as das coisas celestiais e terrestres. Ele trabalhou diligentemente no derretimento do minério e também na exploração de minerais; tem íntimo conhecimento de todo o tipo de arma e implementos utilizados no serviço militar e na caça, além de ser hábil na agricultura e também na medição da terra. É impossível escrever um tratado útil e correto acerca da filosofia experimental sem mencionar

\footnotetext{
${ }^{7}$ Habet fontes salinarum habet et fontes calidos et ex eis fluvios balnearum calidarum. (...) Quae etiam venis metallorum aeris ferri et plumbi et argenti fecunda gignit et lapidem gagatem plurimum optimumque est autem nigrogemmeus et ardens igni admotus incensus serpentes fugat attritu calefactus applicita detinet aeque ut succinum.
}

o nome deste homem. Ademais, ele aspira ao conhecimento por seu valor intrínseco; pois se ele desejasse obter favor real, poderia facilmente encontrar soberanos para lhe honrar e enriquecer."

Este belo tributo a Petrus Peregrinus é um reconhecimento de grande importância, pois vindo de um eminente membro da irmandade da ciência. Além do mais, o próprio Roger Bacon parece ter feito alguma experiência com ímãs anteriormente, pois em sua obra Opus Majus ele faz uma clara distinção entre as duas terminações da pedra-ímã: "o ferro que foi tocado pela pedra-ímã se aproxima do lado que o tocou e se afasta do outro."

Em 1269, Peregrinus se achava envolvido numa expedição militar empreendida por Carlos, Duque de Anjou, que objetivava recuperar, como Rei das Duas Sicílias, a cidade de Lucera, no sul da Itália. Ele servia no que pode ser chamado de divisão de engenheiros militares, construindo máquinas de defesa e ataque. Mesmo neste tipo de trabalho, sua mente se ocupava com problemas práticos e teóricos de outra natureza. Naquele momento, ele estava envolvido com o problema de mecânica prática, de conceber um mecanismo que pudesse manter em movimento uma esfera armilar 8 Absorto na solução do problema, ele começou a considerar outro, muito mais fascinante; o do movimento perpétuo em si mesmo. Para isso, concebeu uma roda incrustada de pedaços de ferro que seriam atraídos por uma pedra-ímã. Acreditando que tivesse inventado um motor magnético perpétuo, que nunca tentou construir, ele escreve uma carta a um amigo, de nome Sygerus (Siger, Syger ou Sigerus), Epistola ad Sigerus ${ }^{9}$

A carta se divide em duas partes. Na primeira parte, $\mathrm{Pe}-$ regrinus se ocupa em explicar tudo que havia descoberto da pedra-ímã. Na segunda parte, se ocupa com o motor magnético e o perpetuus motus.

É na primeira parte que ele demonstra suas habilidades experimentais e avança a ciência do magnetismo de um modo que admirou seus contemporâneos e também seus sucessores.

No primeiro capítulo, o autor declara seu objetivo

"Respondendo a vossa solicitação, vos revelarei, por meio de uma narrativa sem esmero, a inegável, embora oculta, virtude da pedra-ímã, acerca da qual os filósofos até o momento não nos dão informação alguma, porque é característica das boas coisas estarem ocultas na obscuridade até que são trazidas à luz por aplicações de utilidade pública. Escreverei em estilo simples sobre coisas inteiramente desconhecidas do indivíduo comum. Tratarei apenas das propriedades evidentes da pedra-ímã, porque este tratado será parte de uma obra acerca da construção de instrumentos filosóficos. A revelação das propriedades ocultas dessa pedra é como a arte do escultor, pela qual traz à existência figuras e sinais. Embora eu possa considerar evidentes e de inestimável valor as coisas sobre as quais indagas, elas são considera-

\footnotetext{
${ }^{8} \mathrm{~A}$ esfera armilar é um instrumento de astronomia aplicado em navegação que consta de um modelo reduzido do cosmos. O grande globo exterior mostra a esfera celeste; a pequena bola no centro, a Terra.

${ }^{9}$ Uma edição da carta de 1558 trás o seguinte título: PETRI PEREGRINI MARICVRTENSIS: De Magnete, seu Rota perpetui motus, libellus.
}

${ }^{10}$ Os trechos da carta são traduzidos da versão em inglês. 17 
das pelas pessoas comuns como ilusões ou meras criações da imaginação. Mas as coisas que estão ocultas da multidão se tornarão claras aos astrólogos e estudantes da natureza, e constituirão seu prazer, tanto quanto serão de grande auxílio àqueles que são mais velhos e cultos."

Depois de explicar a respeito da qualificação de um bom experimentalista, traindo aqui, talvez, um desejo de se gabar, ele estabelece experimentalmente os seguintes fatos acerca da pedra-ímã.

Fato \#1 - Peregrinus assinala uma posição definida para o que ele chama polos de uma pedra-ímã. Adicionalmente, prova que um fragmento de uma agulha magnética é ainda uma agulha magnética.

"Desejo informar-vos que essa pedra carrega uma semelhança com os céus, como vou demonstrar claramente aqui. Há nos céus dois pontos mais importantes que todos os outros, porque em torno deles, como em torno de pivôs, a esfera celeste gira: estes pontos são chamados, um deles de ártico ou polo norte, o outro de antártico ou polo sul. Do mesmo modo, deves perceber, sem sombra de dúvida, que nessa pedra há dois pontos chamados respectivamente de polo norte e polo sul. Se fordes cuidadoso, poderás descobrir esses dois pontos. Um método de se fazer isso é o seguinte: Com um instrumento por meio do qual cristais e outras pedras são arredondados, seja a pedra-ímã transformada em um globo e então polida. Uma agulha ou uma peça alongada de ferro é então colocada no topo da pedra-ímã e uma linha é traçada na direção da agulha ou ferro, assim dividindo a pedra em duas partes iguais. A agulha é em seguida colocada em outra parte da pedra e outra linha mediana é traçada. Se desejado, essa operação pode ser repetida em muitas partes diferentes, e sem dúvida todas essas linhas se encontrarão em dois pontos tal como todos os meridianos ou círculos azimutais se encontram em dois polos opostos do globo. Um deles é o polo norte, ou outro, o sul. Um segundo método para determinar esses importantes pontos é este: procure o lugar na pedra-ímã esférica supra-mencionada em que a agulha se une mais frequentemente e mais fortemente; este será um dos polos encontrados pelo método anterior. Para determinar este ponto exatamente, parta um pequeno pedaço da agulha, do tamanho de uma unha; então coloque-o no lugar encontrado pelo método recém-descrito. Se o fragmento ficar perpendicular à pedra, então este é, indubitavelmente, o polo procurado; se não, mova o fragmento de ferro em torno até que ele se torne perpendicular; marque este ponto cuidadosamente; no lado oposto, outro ponto deve ser encontrado de modo similar. Se tudo isso for feito corretamente, e se a pedra for homogênea e corresponder a uma boa escolha, esses dois pontos serão diametralmente opostos, como os polos de uma esfera." 17

Fato \#2 - Ele fornece indicações práticas de como determinar qual é o polo norte e qual o sul.

"Tome um vasilhame de madeira redondo, como um prato ou uma bandeja, e coloque nele a pedra de modo a que os dois polos fiquem equidistantes da borda do vasilhame; então o coloque num vasilhame ainda maior, cheio de água, de modo a que o primeiro vasilhame se assemelhe a um homem numa canoa. (...) Quando a pedra for assim disposta, ela girará até que o polo norte se encontre na direção do polo norte dos céus, e o polo sul aponte para o polo sul dos céus." 17

Fato \#3 - Ele estabelece as duas leis fundamentais do magnetismo: polos iguais se repelem e polos opostos se atraem.

"Selecione duas pedras-ímã. Coloque uma em seu vasilhame de modo a flutuar como um homem numa canoa, com seus polos equidistantes da borda do vasilhame. Com as próprias mãos, aproxime o polo norte da outra pedra, do polo sul da que flutua. Esta seguirá a pedra em vossas mãos como se desejando unir-se a ela. Se, ao contrário, aproximares a terminação sul da pedra em vossas mãos à terminação norte da pedra flutuante, o mesmo fenômeno ocorrerá. Saibas então que esta é a lei: o polo norte de uma pedra atrai o polo sul da outra, enquanto o polo sul atrai o norte. (...) Se procederes ao contrário, e aproximares o polo norte de uma pedra ao polo norte da outra, a pedra em vossas mãos parecerá colocar-se em fuga da pedra flutuante. Se o polo sul de uma for aproximado ao polo sul da outra, o mesmo ocorrerá." 17 .

Fato \#4 - Ele mostra que um polo de uma pedra-ímã pode neutralizar um polo mais fraco de mesmo nome, ou mesmo reverter sua polaridade.

"Se quiseres que a pedra, segundo seu natural desejo, atraia o ferro, procedas como se segue: aproximes o polo sul da pedra da terminação norte do ferro (antes determinada) e este seguirá a pedra. Ou, ao contrário, apresente o polo norte da pedra à parte sul do ferro, e este será atraído pela pedra sem nenhuma dificuldade. Se, contudo, fizeres o contrário, isto é, trouxeres a terminação norte da pedra para próximo do polo sul do ferro, notarás que o ferro gira até que seu polo sul se una ao polo norte da pedra. (...) Se uma força for exercida em qualquer dos polos de modo a fazer o polo sul do ferro tocar a terminação sul da pedra, então a característica [virtue, no original] no ferro será facilmente alterada de forma que o que era antes polo sul, agora se tornará polo norte, e vice-versa." 17 
É possível perceber, pela descrição acima, quão extraordinários foram os avanços teóricos e experimentais conseguidos por Peregrinus. Mostra, por meio de seus experimentos, a existência do campo de força em torno da pedra-ímã, lapidada cuidadosamente no formato de uma esfera, campo este que defletiu sua agulha tanto lateral quanto verticalmente. Ele, ademais, traçou as linhas de força e determinou suas direções e também o fato de que elas terminavam nos polos, pois eram meridianos em seu globo. Assim, Peregrinus revelou a presença do campo magnético, uma descoberta que fundamenta todos os desenvolvimentos da eletricidade. Pode-se dizer que ele começou um ciclo que terminaria 550 anos depois, quando Oersted observou sua agulha girar e tomar uma nova posição no campo de força que circundava, não uma pedra-ímã, mas um fio conduzindo corrente.

Seu trabalho mostra também que o método experimental já estava sendo magistralmente usado dois séculos antes de seu pretenso criador, Francis Bacon. Não chega a ser coincidência que Francis Bacon tenha nutrido uma antipatia pública por outro grande experimentalista, este seu contemporâneo, William Gilbert que, aliás, foi um grande admirador de Peregrinus e o descobridor de sua Carta, já então esquecida, que ele cita várias vezes em sua importantíssima obra $D e$ Magnete, Magneticisque Corporibus, et de Magno Magnete Tellure [Sobre os Ímãs, os Corpos Magnéticos e o Grande Ímã Terrestre].

\section{Considerações finais}

Decerto que toda boa história merece ser contada. No entanto, escrever a história não é simplesmente fazer cronologia. Se não encarada apenas como fonte de curiosidades ou cronologia, a história "tem o poder de produzir uma verdadeira transformação na imagem da ciência, em seu importante papel na evolução da humanidade" 18. Assim, é preciso que o historiador da física tenha em mente uma pergunta que o faça delinear seu trabalho, a partir dos documentos que elegeu para isso, assim como o cientista busca responder a uma questão chave que o instigue [19].

A historiografia do eletromagnetismo foi, da Antiguidade à Idade Média, a elucidação daquilo que antes pertencia ao "domínio etéreo", e que passaria, transcorridos alguns séculos, de mera curiosidade a objeto de estudo e trabalho para cientistas, engenheiros e pessoas comuns. E por mais que o acúmulo de esforcos em responder a pergunta "o que é eletricidade?" tenha culminado em maravilhosas inovações no campo da tecnologia, a pergunta ainda comporta muitos desafios, e pode abrir grandes expectativas para o porvir.

\section{Referências}

[1] P.F. Mottelay, Bibliographical History of Electricity and Magnetism Cronologically Arranged (Charles Griffin \& Company Limited, London, 1922).

[2] F. Copleston, A History of Philosophy (Image Books, New York, 1993), v. I.

[3] Aristóteles, Sobre a alma (Imprensa Nacional-Casa da Moeda, Lisboa, 2010), p. 39.

[4] Aristóteles, op. cit. p. 56.

[5] P. Benjamin, History of Electricity: from antiquity to the days of Benjamin Franklin (John Wiley \& Sons, New York, 1898).
[6] Platão, Timeu (C.E.C.H. - Universidade de Coimbra, Coimbra, 1904).

[7] Theophrastus, On Stones (Ohio State University Press, Columbus, 1956).

[8] T.L. Carus, De Rerum Natura (Abril Cultural, São Paulo, 1985)

[9] J.C. Maxwell, Transactions of Cambridge Philosophical Society 10, 155 (1855).

[10] W.D. Weaver, Catalogue of the Wheeler Gift of Books, Pamphlets and Periodicals in the Library of the American Institute of Electrical Engineers (AIEE, New York, 1909).

[11] S. Agostinho, A Cidade de Deus (Editora Universitária São Francisco, Bragança Paulista, 2008), livro 21, cap. iv.

[12] M. Borup, N. Brown, K. Konrad e H. Van Lente, Technology Analysis \& Strategic Management 18, 3 (2006).

[13] D. Alighieri, A Divina Comédia (Editora 34, São Paulo, 1998).

[14] B. Potamian e J.J. Walsh, The Makers of Electricity (Fordham University Press, New York, 1909), p. 6.

[15] W. Gilbert, On the magnet, magnetick bodies also, and on the great magnet the earth; a new Physiology demonstrated by many arguments and experiments (Chiswick press, London, 1900).

[16] S. Agostinho, op. cit. cap. vi.

[17] P. Peregrinus, The Letter of Petrus Peregruinus on the magnete, A.D. 1269 (McGraw Publishing Company, New York, 2011).

[18] M. Bloch, Apologia da História ou o Oficio do Historiador (Zahar, Rio de Janeiro, 2001).

[19] A. Prost, Doze lições sobre a história (Autêntica, Belo Horizonte, 2008), v.2. 